\author{
Professor Ömer İSKENDEROGLU,PhD \\ NigdeÖmerHalisdemir University,Nigde, Turkey \\ E-mail: o.iskenderoglu@ ohu.edu.tr, \\ Assistant Professor Saffet AKDAG, PhD \\ Tarsus University, Mersin, Turkey, \\ E-mail: ekonomisyen@yahoo.com
}

\title{
A COMPARISON OF PORTFOLIO OPTIMIZATION RESULTS WITH FUZZY KONNO-YAMAZAKI LINEAR PROGRAMMING IN BULL AND BEAR MARKETS: THE CASE OF TURKEY ${ }^{1}$
}

\begin{abstract}
In this study, it is aimed to test whether or not the market regimes have impacts on portfolio optimization results by using fuzzy linear programming model.In this context, the bull and the bear market regimes of BIST 100 index as an accepted market indicator, between January 2000 and December 2016, are determined by Markov regime switching model. Portfolio optimization is carried out by using the fuzzy linear programming model for each of two different bulls and two different bear markets determined as the result of the analysis.According to optimization results, the bear markets have similarities within themselves while the bull markets differ. Thus, optimization results in the bull and the bear markets indicate discrepancies.
\end{abstract}

Keywords: Portfolio optimization, fuzzy logic, linear programming, markov regime switching models.

\section{JEL Classification: G11, C45, C61}

\section{Introduction}

The decision-making process of people's lives takes place under uncertainties. Expression ssuch as "probably," "not very clear" and "quite dangerous" which are frequently heard in daily life are the outcome of uncertainties. Therefore, if uncertainties are not taken into account in the decisionmaking process, the expected results may be misleading (Shahraki and Paghaleh, 2011).

The uncertainties within investments affect investors' decisions. Because uncertainties cause a risk when they become measurable. In terms of investors, one pillar of investment decisions constitutes a risk while the other pillar of investment decisions is expected return.In terms of investment decisions, however, the concept of creating a portfolio of various investment instruments in order to minimize risk has been found in finance literature along with the conventional portfolio theory.

\footnotetext{
${ }^{1}$ This research has been supported by Scientific Research Projects Coordination Unit of
} Niğde Ömer HalisdemirUniversity (Project number: SOB 2017/03 DOKTEP). 
Ömer Iskenderoglu, Saffet Akdag

According to the theory, the more diversified the investment instruments to be included in the portfolio, the lower the risk of the portfolio.In modern portfolio theory based on Markowitz (1952), it is stated that the securities that would constitute a portfolio should be chosen in accordance with the degree of correlation between diversified securities.The lower the correlation between securities, the lower the risk of the portfolio.This approach is expressed as a modern portfolio theory and the risk calculation approach is included in the literature as the meanvariance model.

Several different models have been developed to determine the optimal portfolio besides the mean-variance model.The semi-variance approach, the lower partial moment and Konno and Yamazaki (1991) linear programming model which consider risk calculation aspects, the Black and Litterman model which uses different methods in expected return calculations, the index models based on beta coefficients that consider the relationship between securities and macroeconomic factors, and artificial intelligence-based optimization models such as the fuzzy logic are used as an alternative to mean-variance model.In this study, it is aimed to perform portfolio optimization in bull and bear markets using the Konno Yamazaki (KY) linear programming model to compare the obtained results.In this context, only a limited number of studies on portfolio optimization conducted separately in bull and bear markets have been found during the literature review. Portfolio optimization is carried out on the monthly data of the 30 largest and the 30 smallest companies traded in the Malaysian stock market with the average variance and the fuzzy mean-variance model in Mohamad et al. (2010), one of the pioneering studies in this regard. As a result of the analysis, it is stated that the fuzzy meanvariance model had a tendency to decrease especially in the long-run compared to the other models.Kocadağlı and Keskin (2015), conducted portfolio optimization with the fuzzy goal programming (FGP) besides conventional methods such as mean-variance, mean absolute deviation and minimax using daily data of securities in BIST30 index.Three different investment periods are selected in the study. The first and the second investment periods are characterized the bear and the bull markets, respectively. The third investment period is expressed as the one through which the investor profiles who wishes to follow BIST30 index have been examined.

As a result of the analysis, it is stated that the revenue of optimal portfolios generated by conventional methods lags behind the revenue of optimal portfolios generated by the fuzzy logic model. It is also stated that the portfolio returns increase in case of the beta coefficient values of the shares to be placed in the portfolio are negative or less than unity in the period which is expressed as a bear market.In the period referred to as the bull market, on the other hand, it is stated that the revenue of the portfolios comprised of securities with beta coefficients higher than unity tends to be higher.In the third and last period, it is stated that securities that are synchronized with BIST30 index should be selectedin order to create an optimal portfolio.Wang et. al., (2017), compared the fuzzy logic multiobjective portfolio optimization model and the conventional multi-objective 
A Comparison of Portfolio Optimization Results with Fuzzy Konno-Yamazaki Linear Programming in Bull and Bear Markets: The Case of Turkey

portfolio optimization model both by applying daily data of the 30-day securities trading at the New York Stock Exchange (NYSE). As a result of the analysis, it is stated that the multi-objective portfolio optimization model is more successful than the conventional multi-objective portfolio optimization models and that the proposed model market offers more returns in periods when it enters a neutral or upward tendency and the risk is lower when the market is on a downward trend.It can be stated that the studies in the literature generally differ in terms of portfolio optimization results in bull and bear markets.

In this study, Markov regime switching model is used to determine the bull and bear markets using BIST 100 monthly natural logarithmic product between 2000 - 2016.Later on, during these periods, portfolio optimization is carried out separately for the bear and bull markets previously determined by using the closing data of 58 securities, which are continuously tradedin BIST 100.The study consists of five sections within this framework.In the first section, brief information on the risk and expected return along with the portfolio management theories and models are given under the introduction heading.In the second section, studies conducted on the fuzzy logic model in the literatureare mentioned.In the third section, the methods used in the study are introduced.In the fourth section, findings related to the performed analyzes are included.In the last section of the study, the obtained results are interpretedand suggestions are made.

\section{Methodology}

In the study, Markov regime change model is utilized for parametric methods in order to determine the regimes in the market.The basic reason for choosing the Markov regime switching model over the other models is that it gives the probability that switching process would be in time $t$ and regime j(Açıkgöz, 2008).After the bull and bear market regimes in the markets were identified,the fuzzy linear programming model is used for portfolio optimization. The model is preferred since it does not require too many constraints and is practical to apply to large-scale portfolios.

\subsection{Markov Regime Switching Model}

The Markov regime switching model was introduced in the literature with univariate Markov regime switching model developed in Hamilton (1989), and Krolzig (1997), also allowed for a wide range of field use by adapting it to multivariate analyzes (Koy et. al., 2016).The main rationale of the Markov regime switching model is to explain the stochastic process that causes a transition from one regime to another with a Markov chain. The Markov chain is used to model the behavior of a state variable or combination of variables whichare not directly observable in determiningthe presentregime (Bildirici et.al., 2010).

In Hamilton (1989), the contraction and expansion periods of the economy, in other words, the regimes are calculated according to the non-observable random variable $s_{t}$ of integer value (Brooks, 2014). For this purpose, the 2-regime MSAAR (p) model developed in Hamilton (1989) is as follows: 


$$
\begin{aligned}
y_{t} & =\left\{\begin{array}{l}
\phi_{1,0}+\phi_{1,1} y_{t-1}+\cdots+\phi_{1, p} y_{t-p}+\varepsilon_{t} \text { if }\left(s_{t}=1\right) \\
\phi_{2,0}+\phi_{2,1} y_{t-1}+\cdots+\phi_{2, p} y_{t-p}+\varepsilon_{t} \text { if }\left(s_{t}=2\right)
\end{array}\right\} \\
y_{t} & =\phi_{0, s_{t}}+\phi_{1, s_{t}} y_{t-1}+\cdots+\phi_{p, s_{t}} y_{t-p}+\varepsilon_{t}
\end{aligned}
$$

$y_{t}$ : Time-series variable

$\phi:$ Autoregressive lag parameters of the regimes

$s_{t}$ : The values of the regimes

$p$ : Autoregression rank of the model

$\varepsilon_{t}$ : Error terms

In the Markov regime switching model, the regime variable $s_{t}$ cannot be observed directly but the financial time-series $y_{t}$ can be observed.The characteristics of the time series $y_{t}$ that can be observed depend on the unobserved regime variables $s_{t}($ Krolzig, 1997).The Markov regime change model, which explains relations among regimes in a two-regime model, is as follows (Hamilton, 1994):

$$
P\left\{s_{t}=j \mid s_{t-1}=i\right\}=P\left\{s_{t}=j \mid s_{t-1}=i, s_{t-2}=k, \ldots\right\}=p_{i j}
$$

Models and regime transition probabilities matrix expressing the probability of transition between regimes in a 2-regime model are expressed as follows:

$$
\begin{aligned}
& \operatorname{Pr}\left[s_{t}=1 \mid s_{t-1}=1\right]=p_{11}=p \\
& \operatorname{Pr}\left[s_{t}=0 \mid s_{t-1}=1\right]=p_{10}=1-p \\
& \operatorname{Pr}\left[s_{t}=0 \mid s_{t-1}=0\right]=p_{00}=q \\
& \operatorname{Pr}\left[s_{t}=1 \mid s_{t-1}=0\right]=p_{01}=1-q \\
& P=\left[\begin{array}{cc}
q & 1-q \\
1-p & p
\end{array}\right]
\end{aligned}
$$

The values $\left(p_{11}, p_{10}, p_{00}, p_{01}\right)$ that represent the transition probabilities among the regimes must be positive and their sums must be equal to unity $\left(p_{11}+\right.$ $p_{10}=1$ and $p_{00}+p_{01}=1$ ) (Franses and Dijk, 2000).

\subsection{Fuzzy Linear Programming Model}

The concept of fuzzy logic is studied as a subdivision of artificial intelligence studies.It emerged as a product of very valuable works of logic suggestingthe possible existence of the third or fourth etc. options, whereas Aristotelian, bivalent logic stated that a propositionmight be either true or false withouta third alternative (Birgili et. al., 2013). Zadeh (1965), is one of the earliest studies conducted in the field of a fuzzy logic model which defined fuzzy logic as a synonym of fuzzy set theory in abroad sense, and as a structure that provides benefits to the logic system as a form of approximate reasoning in thenarrow sense. Following Zadeh (1965), Bellman and Zadeh (1970), stated that fuzzy logic should 
A Comparison of Portfolio Optimization Results with Fuzzy Konno-Yamazaki Linear Programming in Bull and Bear Markets: The Case of Turkey

be used in the decision-making process. All the parameters in the decision-making process involve fuzziness which causes many problems.Probability software or multi-objective programming models used for the solution of such problems are insufficient (Maleki et. al., 2000).

The fuzzy linear programming model is an extended and blurred version of the classical linear programming model which includes the linear programming model and the fuzzy logic properties.In the fuzzy linear programming model, there are three different solution approaches. These are of Verdegay (1982), Zimmermann (1983), and Werners (1987).In Verdegay (1982), approach, the highest membership level of the fuzzy decision set is not determined.Moreover, since the objective function is not considered as constraints, the solution is not symmetrical. In Zimmermann (1983), approach, the maximum and minimum membership levels are formed by asking the decision-maker.Werners (1987), approach suggested that the maximum and minimum membership levels should not be set by the decision-maker and that it should be achieved using the max-min operation (Verdegay, 1982; Werners, 1987; Zimmermann, 1991).Establishing the membership level with the max-min operation caused Werners (1987), approach to be preferred over other approaches.

The application of the fuzzy linear programming model to portfolio optimizations is used along with the KY linear programming model. As a result of the fuzziness of the objective function, KY linear programming model is transformed into a fuzzy KY linear programming model. The objective function and constraints created by applying the Werners (1987), approach to the fuzzy KY linear programming model can be expressed as follows (Lai and Hwang, 1992).

Objective Function:

$$
\operatorname{Min} Z \sum_{t=1}^{T} \frac{y_{t}}{T}
$$

Constraint 1:

$$
y_{t}-\sum_{j=1}^{n} a_{t j} x_{j} \geq 0 \quad t=1,2, \ldots, T
$$

Constraint 2:

$$
y_{t}+\sum_{j=1}^{n} a_{t j} x_{j} \geq 0 \quad t=1,2, \ldots, T
$$

Constraint 3:

$$
\sum_{j=1}^{n} r_{j} x_{j} \geq \rho M_{0}+\alpha \tau \quad \alpha \in[0,1]
$$

Constraint 4 :

$$
\sum_{j=1}^{n} x_{j}=M_{0}
$$

Given $\alpha \in[0,1]$ with the model, it can be determined at which level of investment should be made to which securities at the satisfaction level determined by solving the expected return of the portfolio according to different satisfaction levels when the model is applied for portfolio optimization. At this phase, the expected target return and risk values corresponding to a certain level of satisfaction can be determined.However, the model cannot provide a complete solution to determine optimal portfolio among various return and risk 
combinations.In this context, the model is first solved for the expected returns of $\rho M_{0}(\alpha=0.1)$ and $\rho M_{0}+\tau(\alpha=1)$, and then objective function values $Z^{0}$ and $Z^{1}$ are found. As the expected return level in the model increases, $Z^{1}>Z^{0}$ since risk would also increase. Membership functions that are created by using $Z^{0}$ and $Z^{1}$ values can be expressed as follows (Shahraki and Paghaleh, 2011):

$$
\begin{gathered}
\mu_{z}(x)=\left\{\begin{array}{lc}
1, & Z<Z^{0} \\
1-\left[Z-Z^{0}\right] / Z^{1}-Z^{0}, & Z^{0} \leq Z \leq Z^{1} \\
0, & Z>Z^{1}
\end{array}\right\} \\
\mu_{k}(x)=\left\{\begin{array}{lc}
0, & \sum_{j=1}^{n} r_{j} x_{j}<\rho M_{0} \\
{\left[\sum_{j=1}^{n} r_{j} x_{j}-\rho M_{0}\right] / \tau,} & \rho M_{0} \leq \sum_{j=1}^{n} r_{j} x_{j} \leq \rho M_{0}+\tau \\
1, & \sum_{j=1}^{n} r_{j} x_{j}>\rho M_{0}+\tau
\end{array}\right\}
\end{gathered}
$$

The objective function and constraints of the fuzzy KY linear programming model represented by the membership function of the expected return $\left(\mu_{k}(x)\right)$ and the membership function of objective $\mu_{z}(x)$ using the max-min method can be shown as follows (Shahraki and Paghaleh, 2011):

Objective function:

$$
\operatorname{Max} \alpha\left(\mu_{z}(x) \geq \alpha, \mu_{k}(x) \geq \alpha, x \geq 0, \alpha \in[0,1]\right)
$$

Constraint 1:

$$
\sum_{t=1}^{T} y_{t} / T+\alpha\left(Z^{1}-Z^{0}\right) \leq Z^{1}
$$

Constraint 2 :

$$
y_{t}-\sum_{j=1}^{n} a_{t j} x_{j} \geq 0 \quad t=1,2, \ldots, T
$$

Constraint 3:

$$
y_{t}+\sum_{j=1}^{n} a_{t j} x_{j} \geq 0 \quad t=1,2, \ldots, T
$$

Constraint 4:

$$
\sum_{j=1}^{n} r_{j} x_{j} \geq \rho M_{0}+\alpha \tau \quad \alpha \in[0,1]
$$

Constraint 5:

$$
\sum_{j=1}^{n} x_{j}=M_{0} \quad\left(0 \leq x_{j} \leq \mu_{j}, y_{t} \geq 0\right)
$$

At the acceptable level of satisfaction $(\alpha \in[0,1])$ by using the model, it can be calculated which securities are invested at which ratios.The following are the parameters used in the model:

$T \quad$ : The number of examined periods,

$t \quad$ : Any time $t$ over $T$ periods,

$\rho \quad:$ The expected rate of return,

$r_{j} \quad:$ The average rate of return of the $\mathrm{j}^{\text {th }}$ security,

$r_{j t} \quad$ : The rate of return of the $j^{\text {th }}$ security in any time $t$, 
A Comparison of Portfolio Optimization Results with Fuzzy Konno-Yamazaki Linear Programming in Bull and Bear Markets: The Case of Turkey

$$
\begin{array}{ll}
a_{t j} & : \text { The risk of the } j^{t h} \text { security }\left(r_{j t}-r_{j}\right) \\
x_{j} & : \text { The share of investment on the } j^{t h} \text { security, } \\
\mu_{j} & : \text { The upper limit of the investment on the } j^{t h} \text { security, } \\
M_{0} & : \text { Total amount of investment, } \\
\rho M_{0} & : \text { The amount of expected return, } \\
y_{t} & : \text { The auxiliary variable, } \\
\tau & : \text { The known tolerance value of expected rate of return } \\
\alpha & : \text { The level of return demanded }
\end{array}
$$

\section{Numerical Example}

The application of the study consists of two phases. Firstly, the periods of the bull and the bear markets are determined by the Markov regime switching model using natural logarithm of the monthly BIST 100 index within the period under examination. Then, portfolio optimization is carried out with the fuzzy Konno Yamazaki linear programming model for each identified bull and bear markets.

\subsection{Determining Bull and Bear Markets with Markov Regime Switching Model}

By using BIST 100 index data set and the Markov regime switching model, the bull and bear market periods in the related data set can be determined.First of all, in order to determine the appropriate autoregressive lag and the MS (Markov Switching) model, the Markov regime switching models with coherent transition matrices and robustness test results which satisfy non-linearity condition are given in Table 1.

\section{Table 1: The results of Markov regime switching models}

\begin{tabular}{lcccc}
\hline Model & Log-likelihood & AIC & LR & Davies \\
\hline MSIH 2 (1) & 196.431 & -1.876 & $46.615^{*}$ & 0.000 \\
MSIH 2 (2) & 196.563 & -1.867 & $46.368^{*}$ & 0.000 \\
MSIH 2 (3) & 195.666 & -1.857 & $46.317^{*}$ & 0.000 \\
MSIH 2 AR 1 & 197.363 & -1.875 & $45.932^{*}$ & 0.000 \\
MSIH 2 AR 2 & 196.539 & -1.867 & $46.319^{*}$ & 0.000 \\
MSIH 2 AR 3 & 195.659 & -1.857 & $46.303^{*}$ & 0.000 \\
MSIH 2 AR 1 (1) & 196.422 & -1.875 & $46.596^{*}$ & 0.000 \\
MSIH 2 AR 2 (1) & 195.586 & -1.867 & $47.111^{*}$ & 0.000 \\
MSIH 2 AR 1 (2) & 195.468 & -1.875 & $47.372^{*}$ & 0.000 \\
MSIH 2 AR 2 (2) & 195.452 & -1.874 & $46.611^{*}$ & 0.000 \\
\hline
\end{tabular}

*: significant at $1 \%$ significance level.

In Table 2, Markov switching models are given comparatively according to various lags and autoregressive lag cases. Accordingly, the models with incoherent transition matrices and robustness test results which do not satisfy nonlinearity are excluded. Under these criteria, MSIH 2 (1) model with lag-1having the lowest 
Ömer Iskenderoglu, Saffet Akdag

Akaike (AIC) information criterion is chosen.Table 2 presents the test results of MSIH 2 (1) model with lag-1.

Table 2: Criteria of a lagged MSIH 2 (1) model

\begin{tabular}{lcc}
\multicolumn{1}{c}{ Model: MSIH 2 (1) } & Coefficients & t Prob. \\
\hline Constant (Regime 1) (Bear Market) & -0.006 & 0.768 \\
Constant (Regime 2) (Bull Market) & $0.015^{* *}$ & 0.016 \\
Sigma (Regime 1) & $0.150^{*}$ & 0.000 \\
Sigma (Regime 2) & $0.067^{*}$ & 0.000 \\
LR-test Chi ${ }^{2}$ (4) & $45.952^{*}$ & 0.000 \\
Davies Probability Value & & 0.000 \\
Normality test: Chi ${ }^{2}(2)$ & 0.750 & \\
ARCH 1-5 test: F(5.299) & 0.376 & 0.687 \\
Portmanteau(36): Chi $^{2}(36)$ & 32.742 & 0.540 \\
& & 0.578 \\
\hline
\end{tabular}

*: significant at $1 \%$ significance level.

**: significant at 5\% significance level.

Upon examining Table 2, it is seen that BIST 100 index data set which is used in analysis according to LR (Likelihood Ratio) linearity and Davies test results from the test statistics of the model exhibit nonlinear structure and two regimes are formed.In this context, when the relevant coefficients (sigmas) are examined, the first regime is determined as highly volatile while the second regime is characterized by lower volatility. The return for the first regime is negative, yet the return for the second regime is positive.Thus, it can be said that the first and the second regimes represent the bear and the bull markets, respectively. When the results of model-related robustness tests such as normality, ARCH, and Portmanteau test are considered, it is seen that there is no normal variance of the error terms, and hence no autocorrelation. Table 3 indicates the regime transition matrices of BIST 100 index data set.

Table 3: The regime transition probability matrix

\begin{tabular}{|c|c|c|c|c|}
\hline & Regime 1 & Regime 2 & $\begin{array}{c}\text { Number of } \\
\text { Observations } \\
\text { (Months)-(\%) }\end{array}$ & $\begin{array}{l}\text { Average } \\
\text { Duration } \\
\text { (Months) }\end{array}$ \\
\hline $\begin{array}{l}\text { Regime 1 } \\
\text { (Bear Market) }\end{array}$ & 0.968 & 0.032 & $67-33 \%$ & 33.50 \\
\hline $\begin{array}{l}\text { Regime } 2 \\
\text { (Bull Market) }\end{array}$ & 0.009 & 0.991 & $136-67 \%$ & 68 \\
\hline $\begin{array}{l}\text { Upon } \\
\text { probability of } \\
\text { bull market) is } \\
\text { volatility, negati } \\
t+1 .\end{array}$ & $\begin{array}{l}\text { nining the } \\
\text { hing to re } \\
\text { o, while tl } \\
\text { return, and }\end{array}$ & $\begin{array}{l}\text { natrix of } \\
2 \text { (with } \\
\text { probability } \\
\text { bear mark }\end{array}$ & $\begin{array}{l}\text { Sime transition } \\
\text { volatility, posi } \\
\text { f staying in reg } \\
\text { is about } 97 \% \text { in }\end{array}$ & $\begin{array}{l}\text { babilities, } \\
\text { return and } \\
1 \text { (with } h \\
\text { ition from }\end{array}$ \\
\hline
\end{tabular}


A Comparison of Portfolio Optimization Results with Fuzzy Konno-Yamazaki Linear Programming in Bull and Bear Markets: The Case of Turkey

Similarly, the probability of switching to regime 1 (with high volatility, negative return,and the bear market) is $1 \%$, while the probability of staying in regime 2 (with low volatility, positive return and the bull market) is about99\% in thetransitionfrom $t$ to $t+1$.According to the results, persistence characteristics are observed in both regimes.The average durations of stay in regime 1(which is expressed as the bear market) and regime 2 (which is expressed asabull market) are 33.50 and 68 months, respectively.According to the results, 67\% (136 months) of the analyzed period is in the bull market period and 33\% (67 months) in the bull market period.It is seen that the bull market has higher ratiosin terms of total period, average duration of stay and probability in comparison to the bear market.In Table 4, date intervals covering the bull and the bear market periods are given.

Table 4: The date intervals defined as the bull and the bear markets

\begin{tabular}{cccc|cccc}
\hline Periods & $\begin{array}{c}\text { Bear Market } \\
\text { Duration } \\
\text { (Months) }\end{array}$ & Probability & $\begin{array}{c}\text { Standard } \\
\text { Deviation }\end{array}$ & Periods & $\begin{array}{c}\text { Bull Market } \\
\text { Duration } \\
\text { (Months) }\end{array}$ & Probability & $\begin{array}{c}\text { Standard } \\
\text { Deviation }\end{array}$ \\
\hline $\begin{array}{c}2000(2)- \\
2004(2)\end{array}$ & 49 & 0.97 & 0.20 & $\begin{array}{c}2004(3)- \\
2007(11)\end{array}$ & 45 & 0.95 & 0.12 \\
$\begin{array}{c}2007(12)- \\
2009(5)\end{array}$ & 18 & 0.87 & 0.17 & $\begin{array}{c}2009(6)- \\
2016(12)\end{array}$ & 91 & 0.98 & 0.13 \\
\hline
\end{tabular}

As shown in Table 4, there are two different bears and two different bull markets based on the results of the analysis.The first bear market includes the period February 2000 - February 2004, while the second bear market includes the period December 2007 - May 2009.

The first bull market covers March 2004 - November 2007, while the second bull market covers June 2009 - December 2016.In this context, it is detected that a total of 49 month period between February 2000 -February 2004 and a total of 18 month period between December 2007 - May 2009 could be classified as the bear market with probabilities of $97 \%$ and $87 \%$, respectively. On the other hand, it is detected that a total of 45 month period between March 2004 November 2007 and a total of 91 month period between June 2009 - December 2016 could be classified as the bear market with probabilities of $95 \%$ and $98 \%$, respectively. Nonetheless, the average standard deviation of totally 58 securities subject to the analysis is calculated as 0.20 in the first bear market period and 0.17 in the second bear market period, whileit is found as 0.12 in the first bull market and 0.13 in the second bull market.

\subsection{Portfolio Optimization with Fuzzy Konno-Yamazaki Linear Programming Model}

Portfolio optimization has been tried to be performed by utilizing the fuzzy KY linear programming model with the monthly frequency data of totally 58 securities which are firstly analyzed in the bull markets and then in the bear markets.Following the calculation of monthly returns on the securities subject to 
analysis, the average expected rates of return on the securities $(\rho)$ and the maximum average expected rates of return on the $\operatorname{securities}\left(\rho_{\max }\right)$ are found.After calculating of the tolerance $(\tau)$ of the expected return which represents the difference of the average return from the maximum average yield, the membership function of the expected return is established.

Within the optimization process, the objective function becomes fuzzy by the Werners (1987) approach.The objective function in the model is the minimization of the sum of the $y_{t}$ function calculated for each period.The $y_{t}$ function is calculated by subtracting the rates of return on the securities in period $t$ from the average rates of return on the relevant securities as the coefficients of the decision variables and taking the absolute value of this outcome. Thus, the objective function to be minimized for each period considered as either a bull or a bear market is formed by using the function $y_{t}$ calculated for each period.The variable $y_{t}$ is the absolute value of the difference between the rate of return on each security in time $t$ and the average return on each related security denoted as

$$
a_{t j}=\left(r_{j t}-r_{j}\right), \sum_{t=1}^{T}\left|\sum_{j=1}^{n} a_{t j} x_{j}\right| .
$$

Therefore, upon the possibility that the variables in the absolute value may be positive or negative, the related variables with plus and minus signs are included in the model as the first and the second constraints. The third constraint is that the sum of the multiplication of the share of investment made to each security by the average return on each security must be greater than or equal to the multiplication of average return (or expected return) by the total investment amount. This constraint has previously been expressed as $\sum_{j=1}^{n} r_{j} x_{j} \geq \rho M_{0}+\alpha \tau$. Accordingly, the constraint is defined as $Z^{0}$ for $\alpha=0$ and $Z^{1}$ for $\alpha=1$.The fourth and last constraint is the one that the sum of the variables $x$ representing the weight of the investment shares must equal to unity. Equations expressing the objective function and constraints for the solution of $Z^{0}$ and $Z^{1}$ are given in the appendix.

By solving the model, the values of $Z^{0}$ and $Z^{1}$ of the objective function are obtained. $Z^{0}$ represents the risk value of the optimal portfolio corresponding to complete satisfaction, and $Z^{1}$ represents the risk value of the optimal portfolio corresponding to complete dissatisfaction. The membership function is created by substituting $Z^{0}$ for $\alpha=0$ and $Z^{1}$ for $\alpha=1$.

By substituting the membership function, the fuzzy objective and resource linear programming model is transformed into the standard linear programming model.In this regard, the objective function and the equations expressing the constraints are given in the appendices.Upon the solution of the model established by fuzzy KY linear programming, the satisfaction level $\alpha$ is found through which the optimal portfolio would be formed. This value also determines the optimal portfolio that provides the highest return per unit risk (Pelitli, 2007: 142).The optimal portfolio corresponding to the determined $\alpha$ level is obtained from the membership function of minimized risk and maximized return. The portfolio optimization results of the bull and bear markets according to the analysis are given in Table 5 and Table 6. 
A Comparison of Portfolio Optimization Results with Fuzzy Konno-Yamazaki Linear Programming in Bull and Bear Markets: The Case of Turkey

Table 5: The result regarding the bull markets

\begin{tabular}{ccccc}
\hline Markets & $\begin{array}{c}\text { Number of } \\
\text { Assets in } \\
\text { the } \\
\text { Portfolio }\end{array}$ & $\begin{array}{c}\text { Portfolio Risk } \\
\text { According to } \\
\text { Konno-Yamazaki } \\
\text { Model }\end{array}$ & $\begin{array}{c}\text { Portfolio Risk } \\
\text { According to } \\
\text { Markowitz Model }\end{array}$ & $\begin{array}{c}\text { Return on } \\
\text { Portfolio }\end{array}$ \\
\hline $\begin{array}{c}\text { The First Bull } \\
\text { Market }\end{array}$ & 5 & 0.032 & 0.085 & 0.060 \\
$\begin{array}{c}\text { The Second } \\
\text { Bull Market } \\
\text { Average }\end{array}$ & 3 & 0.146 & 0.455 & 0.086 \\
\hline
\end{tabular}

According to Table 5, the bull markets exhibit similarities in terms of the number of assets in the optimal portfolio, the return on portfolio and the risk involved.In this context, it can be stated that portfolio optimization results in the bull markets differ.

Table 6: The results regarding the bear markets

\begin{tabular}{ccccc}
\hline Markets & $\begin{array}{c}\text { Number of } \\
\text { Assets in } \\
\text { the } \\
\text { Portfolio }\end{array}$ & $\begin{array}{c}\text { Portfolio Risk } \\
\text { According to } \\
\text { Konno-Yamazaki } \\
\text { Model }\end{array}$ & $\begin{array}{c}\text { Portfolio Risk } \\
\text { According to } \\
\text { Markowitz Model }\end{array}$ & $\begin{array}{c}\text { Return on } \\
\text { Portfolio }\end{array}$ \\
\hline $\begin{array}{c}\text { The First } \\
\text { Bear Market }\end{array}$ & 3 & 0.077 & 0.198 & 0.066 \\
$\begin{array}{c}\text { The Second } \\
\text { Bear Market }\end{array}$ & 3 & 0.051 & 0.146 & 0.068 \\
Average & 3 & 0.064 & 0.172 & 0.067 \\
\hline
\end{tabular}

According to Table 6, it can be said that in the bear markets exhibit similarities regarding the return on the optimal portfolio generated by the fuzzy KY linear programming model, the number of assets, and the risk involved.In this context, it can be stated that the portfolio optimization results show similarity in the bear markets.

\section{Conclusion}

In this study, it is aimed to compare the optimal portfolios generated by the fuzzy KY linear programming model in both the bull and the bear markets.Firstly, the bull and the bear markets within the relevant date intervals (January 2000 December 2016) are determined by employing the Markov regime switching model on the basis of the natural logarithmic returns of BIST 100 index with monthly frequency. Markov regime switching model has revealed that there are two different bears and two different bull markets.For the bull and the bear markets identified during the next phase of the study, portfolio optimization is carried out with 58 securities that continued their existence throughout the sample period in BIST 100 index using the fuzzy KY linear programming model.The results 
Ömer Iskenderoglu, Saffet Akdag

obtained from portfolio optimization indicate that the returns and risks of the optimal portfolios created in the bear markets have similar characteristics in terms of the number of securities in the portfolio. In the bull market, however, there are differences regarding the returns on the generated optimal portfolios, the number of securities in the portfolioand risks involved.

This study is conducted to determine whether or not the portfolio optimization results, which constitute the aim of the study in this context, differ in the bull and the bear markets. Consequently, it is concluded that portfolio optimization results are different in both markets.Furthermore, when the bull and the bear markets are considered as a whole, the optimal portfolios created in the bear markets offer lower risk, while the portfolios created in the bull markets offer higher returns, which areconsistent with the results of Wang et al., (2017).

Upon assessment of the results of the study in terms of investors, it may be advisable for potential investors to follow active portfolio strategies in the bull markets, and to follow the passive management strategies in the bear markets. However, the obtained results are achievedvia the fuzzy KY linear programming model.For the future studies, the use of other optimization models such as meanvariance, semi-variance, and index models for portfolio optimization in the bull and the bear markets and the realization of analyzes in different country markets would contribute to the literature in the sense of generalizing the results.

\section{REFERENCES}

[1] Açıkgöz, Ş. (2008), An Analysis of Business Cycles under Regime Shifts: The Turkish Economy and Industrial Sector; Dokuz Eylül Üniversitesi

İktisadiveİdariBilimlerFakültesiDergisi,23, 135-151;

[2] Bellman, R.E.and Zadeh, L.A. (1970), Decision-Making in a Fuzzy

Environment; Management Science, 17:141-164;

[3] Bildirici, M., Alp, E.A.,Bozoklu, Ü.AndErsin, Ö.ö. (2010), Iktisatta KullanılanDoğrusalOlmayan Zaman SerisiYöntemleri;TürkmenKitabevi, İstanbul;

[4] Birgili, E.,Sekmen, F.and Esen, S.(2013), BulanıkMantik Yaklaşımıy laFinansalYönetim Uygulamalart: BirLiteratürTaraması; Uluslararası YönetimíktisatveIşsletmeDergisi, 9:121-136;

[5] Brooks, C. (2014), Introductory Econometrics for Finance; Cambridge University Press; Newyork;

[6] Franses, P.H. and Dijk, D.V. (2000), Nonlinear Time Series Models in

Empirical Finance, Cambridge Universtiy Press, Newyork;

[7] Hamilton, J.D. (1989),A New Approach to the Economic Analysis of

Nonstationary Time Series and the Business Cycle; Econometrica, 57:357-384;

[8] Hamilton, J.D. (1994),Time Series Analysis, Princeton University Press, New Jersey; 
A Comparison of Portfolio Optimization Results with Fuzzy Konno-Yamazaki Linear Programming in Bull and Bear Markets: The Case of Turkey

[9] Kocadağlı, O. and Keskin, R. (2015), ANovel Portfolio Selection Model Based on Fuzzy Goal Programming with Different Importance and Priorities; Expert Systems with Applications, 42:6898-6912;

[10]Konno, H. andYamazaki, H. (1991),Mean-Absolute Deviation Portfolio Optimization Model and Its Applications to Tokyo Stock Market; Management Science, 37:519-531;

[11] Koy, A.,Çetin, G. and Ersan, İ. (2016),UluslararasiKıymetli Metal PiyasalarınınRejim Dinamikleri,MaliyeFinans Yazıları, 107:25-40;

[12] Krolzig, H.M. (1997),Markov Switching Vector Autoregressions: Modeling, Statistical Inference, and Application to Business Cycle Analysis;Springer Verlag, Berlin;

[13] Lai, Y.J. and Hwang, C.L. (1992),Fuzzy Mathematical Programming, in Fuzzy Mathematical Programming; Springer, Heidelberg, Berlin;

[14] Maleki, H.R., Tata, M. andMashinchi, M.(2000),Linear Programming with Fuzzy Variables; Fuzzy Sets and Systems, 109:21-33;

[15] Markowitz, H. (1952), Portfolio Selection; The Journal of Finance, 7:77-91; [16] Mohamed, Z., Mohamed, D.and Samat, O. (2010), Portfolio Selection

Using Fuzzy Mean-Variance Approach; Australian Journal of Basic and Applied Sciences, 4:3713-3720;

[17] Shahraki, A.R. and Paghaleh, M.J. (2011),Ranking the Voice of Customer with Fuzzy DEMATEL and Fuzzy AHP; Indian Journal of Science and Technology, 4:1763-1772;

[18] Pelitli, D.(2011), Portföy AnalizindeBulanıkMantık YaklaşımıveUygulama Örneği;YayınlanmamışYüksekLisansTezi,PamukkaleÜniversitesiSosyalBilimler Enstitüsü;

[19] Verdegay, J.L. (1982),Fuzzy Mathematical Programming, in: M.M. Gupta, E. Sanchez (Eds.), Fuzzy Information and Decision Processes;North-Holland, Amsterdam;

[20] Wang, B., Li, Y. andWatadac, J. (2017),Multi-Period Portfolio Selection with Dynamic Risk/Expected-Return Level under Fuzzy Random Uncertainty; Information Sciences, 385:1-18;

[21] Werners, B. (1987),An Interactive Fuzzy Programming System; Fuzzy Sets and Systems, 23:131-147;

[22] Zadeh, L.A. (1965),Fuzzy Sets; Information and Control, 8:338-353;

[23] Zimmermann, H.J. (1983),F uzzy Mathematical Programming; Computers \& Operations Research, 10:291-298;

[24] Zimmermann, H.J. (1991), Fuzzy Set Theory and Its Applications; Kluwer Academic Publishers, Massachusetts; 
Ömer Iskenderoglu, Saffet Akdag

\begin{tabular}{|c|c|c|c|c|c|}
\hline \multicolumn{6}{|c|}{$\begin{array}{l}\text { Appendix } 1 . \\
\text { Table 7: Securities included in the analysis }\end{array}$} \\
\hline Variables & $\begin{array}{c}\text { Security } \\
\text { Code }\end{array}$ & Security's Name & Variables & $\begin{array}{c}\text { Security } \\
\text { Code }\end{array}$ & Security's Name \\
\hline $\mathrm{X} 1$ & AFYON & AfyonÇimento & $\mathrm{X} 30$ & IZMDC & İzmir DemirÇelik \\
\hline $\mathrm{X} 2$ & AKBNK & Akbank & X31 & KRDMD & KardemirDemirÇelik \\
\hline $\mathrm{X} 3$ & AKSA & AkrilikKimya & $\mathrm{X} 32$ & KARTN & KartonSanayi \\
\hline $\mathrm{X} 4$ & ALGYO & Alarko GYO & $\mathrm{X} 33$ & $\mathrm{KCHOL}$ & Koç Holding \\
\hline $\mathrm{X} 5$ & ALARK & Alarko Holding & X34 & KONYA & Konya Çimento \\
\hline X6 & ANACM & Anadolu Cam & $\mathrm{X} 35$ & KORDS & KordsaTekniktekstil \\
\hline $\mathrm{X} 7$ & ARCLK & Arçelik & X36 & METRO & Metro Holding \\
\hline $\mathrm{X} 8$ & ASELS & Aselsan & X37 & MGROS & Migros \\
\hline X9 & AYGAZ & Aygaz & $\mathrm{X} 38$ & NTTUR & Net Turizm \\
\hline $\mathrm{X} 10$ & BAGFS & $\begin{array}{l}\text { BandırmaGübre } \\
\text { Fab. }\end{array}$ & X39 & NETAS & Netaş Tel. \\
\hline $\mathrm{X} 11$ & BANVT & BandırmaYem & $\mathrm{X} 40$ & NUGYO & Nurol GYO \\
\hline $\mathrm{X} 12$ & BRISA & Bridgestone Lastik & $\mathrm{X} 41$ & OTKAR & OtokarotobüsKar. \\
\hline $\mathrm{X} 13$ & CLEBI & ÇelebiHavaServis & $\mathrm{X} 42$ & PARKME & Park Elektrik \\
\hline $\mathrm{X} 14$ & CEMTS & ÇemtaşÇelikMak. & $\mathrm{X} 43$ & PETKM & Petkim Petro Kimya \\
\hline $\mathrm{X} 15$ & DEVA & Deva Holding & $\mathrm{X} 44$ & SAHOL & Sabancı Holding \\
\hline $\mathrm{X} 16$ & DOHOL & Doğan Holding & $\mathrm{X} 45$ & SASA & Sasa Polyester \\
\hline $\mathrm{X} 17$ & ECILC & Eczacıbaşı̇llaç & $\mathrm{X} 46$ & SISE & T.Şişeve Cam Fab. \\
\hline $\mathrm{X} 18$ & EGEEN & EgeEndüstri & $\mathrm{X} 47$ & TSKB & $\begin{array}{c}\text { Türkiye Sınai } \\
\text { veKalkınma Ban. }\end{array}$ \\
\hline X19 & ENKAI & Enka İnşaat & $\mathrm{X} 48$ & TATGD & Tat Gıda \\
\hline $\mathrm{X} 20$ & ERBOS & EreğliBoru San. & $\mathrm{X} 49$ & KIPA & Tesco Kipa \\
\hline $\mathrm{X} 21$ & EREGL & EreğliDemirÇelik & X50 & TOASO & TofaşTürk Oto. \\
\hline $\mathrm{X} 22$ & FROTO & Ford Oto San. & $\mathrm{X} 51$ & TRKCM & Trakya Cam \\
\hline $\mathrm{X} 23$ & GARAN & GarantiBankası & X52 & TUPRS & Tüpraş \\
\hline $\mathrm{X} 24$ & GLYHOL & $\begin{array}{l}\text { Global Yat. } \\
\text { Holding }\end{array}$ & X53 & THYAO & TürkHavaYolları \\
\hline $\mathrm{X} 25$ & GOODY & Goodyear Lastik & X54 & ULKER & Ülker Gıda \\
\hline $\mathrm{X} 26$ & GSDHOL & GSD Holding & X55 & VKGYO & Vakıf GYO \\
\hline $\mathrm{X} 27$ & GUBRF & GübreFabrikaları & X56 & VESTEL & Vestel \\
\hline $\mathrm{X} 28$ & ISCTR & İşbank C & X57 & YKBNK & YapıKrediBankası \\
\hline $\mathrm{X} 29$ & ISGYO & İş GYO & $\mathrm{X} 58$ & YATAS & Yataş \\
\hline
\end{tabular}

